\title{
United in Diversity? \\ The Consolidation of Cultural Values among EU Member States and Candidates
}

\author{
Plamen Akaliyski*, University of Oslo
}

\section{Acknowledgements}

The author is thankful for feedback from Torkild Lyngstad, Christian Welzel, Michael Minkov, Hans-Dieter Klingemann, Arne Mastekaasa, Joseph Hien, Cathrine Holst, Eduard Ponarin, as well as from participants in the PhD seminars at the Department of Sociology and Human Geography, UiO; IACCP European Congress "From a Cross-Cultural Perspectives: Conflict and Cooperation in Shaping the Future of Europe", July 2017 in Warsaw, Poland; Ph.D. and Post-Doc Seminar and Conference 'Global and Cross-Cultural Organizational Research', June 2017 in Maastricht, Netherlands; WAPOR Regional Conference "Survey Research and the Study of Social and Cultural Change", November 2016 in Moscow, Russia; Congress of IACCP "Honoring Traditions and Creating the Future", August 2016 in Nagoya, Japan. The research was partly funded by the Russian Academic Excellence Project '5-100'. Any opinions expressed are those of the author alone.

\footnotetext{
* Department of Sociology and Human Geography, University of Oslo, Norway, and Laboratory for Comparative Social Research, Higher School of Economics, Moscow, Russia. Email: plamen.akaliyski@sosgeo.uio.no
} 


\begin{abstract}
The European Union (EU) is considered a unique economic and political union that integrates most of the European countries. This article focuses on the cultural aspect of the European integration that has been increasingly debated in the course of deepening and widening of integration as well as regarding the legitimation crisis of the EU. Among the main goals of the $E U$ is to promote certain values, which raises the question whether it has been efficient in (or enabled the) shortening the cultural value gaps among the participating countries. World polity and institutional isomorphism theories suggest that cultural values trickle down in a vertical manner from the institutions of EU to its member states and candidates. Furthermore, hybridization theory postulates that values diffuse horizontally through intensified interactions enabled by the EU. These two perspectives imply the possibility of cultural convergence among countries associated with the EU. By contrast, the culture clash theorem assumes that differences in cultural identity prevent value convergence across countries; growing awareness of such differences may even increase the preexisting distance in cultural values. To test these different scenarios I compare distances across pairs of countries in emancipative and secular values (Welzel 2013) using combined repeated cross-sectional data from the EVS and WVS gathered between 1992 and 2011. I find that the longer a country has been part of the EU the more closely its values approximate those of the EU founding countries, which in turn are the most homogenous. Initial cultural distance to the founders' average values appears irrelevant to acquiring membership or candidacy status. However, new member states experienced substantial cultural convergence with old member states after 1992, as did current candidates between 2001 and 2008. Since 1992 nations not participating in the integration process have diverged substantially from EU members, leading essentially to a cultural polarization of Europe. The findings are independent of (changes in) economic disparities and suggest the importance of cultural diffusion as one of the fundamental mechanisms of cultural change.
\end{abstract}

\title{
INTRODUCTION
}

Seven decades after the start of European integration, geopolitical, migratory and economic challenges are threatening its cohesion. The congruence of cultural values may be an essential ingredient for achieving further integration and for responding to current and future problems (Guiso et al. 2016). Among current EU member states, value differences rooted in each of the three main religious traditions in Europe-Protestantism, Catholicism and Orthodoxy-are considered the causes of misunderstandings that impede collective action to deal with the Euro crisis (Hien 2017). One of the key debates over the last decades in European integration studies, fueled by the so-called no-demos thesis (Weiler 1995), concerns the question of whether transnational political integration requires common cultural values and identities. According to Habermas (2012), the legitimacy crisis of the EU can be solved as long as there is a commitment to shared democratic values among participating countries. 
Evidently, European countries differ considerably in their cultural values, and each EU expansion further increases the EU's diversity (Gerhards 2007). Cross-national cultural differences are associated with a wide range of social outcomes, particularly the quality of democracy, effective governance, civic activism and generalized trust (Welzel 2013). The cultural distance between nations is important for institutional integration within the EU (Guiso et al. 2016) and is a predictor of economic exchange (Guiso et al. 2009; Tadesse \& White 2010), interstate conflict (Bove \& Gokmen 2016) and migration between developed countries (Belot $\&$ Ederveen 2012). The large cultural differences between old, new and candidate states have been described as a barrier to European integration (Gerhards 2007). Cultural values are considered relatively stable societal characteristics (Inglehart \& Baker 2000; Schwartz 2006). However, it is worth investigating whether the considerable societal transformations since the early 1990s in relation to European integration allow for a certain amount of plasticity in societal cultures.

The EU has proven transformative of national economies and political institutions, but we do not know whether it has the potential to gradually reduce the cultural gaps between its member states. Some scholars claim that culture has become the focus of the "third wave" of European integration, which aims to strengthen European identity and increase legitimacy by transcending the idea of shared values and a common cultural heritage (Lahdesmaki 2016). "The EU not only has an interest to further this congruence, but is also in a unique position to do so" (Gerhards et al. 2009: 517).

Despite its significance for the future of the European project, the question of whether the process of European integration brings the cultures of participating countries closer together over time remains empirically untested. Previous studies relying on cross-sectional data indicate pronounced cultural differences between EU members and nonmembers (Akaliyski 2017; Gerhards 2007, 2008, 2010; Gerhards \& Hoelscher 2003; Gerhards \& Lengfeld 2006; Gerhards et al. 2009), but we know little about the dynamics of those differences over time and the nature of the causal relationship.

This paper fills this gap by comparing cultural value distances across nations using dyadic regressions on repeated cross-sections of data from the European Value Study (EVS) and World Value Survey (WVS) gathered between 1992 and 2011. The analysis dissects cross-sectional patterns of value similarities and inspects temporal processes of cultural convergence and divergence among countries according to their level of involvement in the EU. Whether participation in European integration leads to value convergence is an important empirical question, considering the political and geopolitical significance of the EU. An answer to this question also tests the credibility of highly influential (but perhaps controversial) speculations regarding the cultural effects of globalization; that is, whether the increased frequency of cultural interactions leads to cultural convergence or divergence. In addition, the paper contributes to the debate about the factors determining cross-national value differences and similarities. The theoretical debate is dominated by proponents of the supremacy of historical legacies (such as Huntington 1996) and modernization theorists underlining the importance of socioeconomic development (Inglehart \& Baker 2000). A smaller number of empirical studies 
have considered the possibility that values can diffuse across national borders (Bonikowski 2010; Deutsch \& Welzel 2016). Empirical tests of the convergence and divergence hypotheses with a large number of nations do not yet exist.

\section{THEORETICAL FRAMEWORK}

\section{Cultural convergence}

Cultural convergence describes any significant reduction in cultural distance between a group of countries. I adhere to the conventional conceptualization of culture as the aggregate configuration of societal values that is most typical for the population of a country (Hofstede 1991; Schwartz 2006). I also follow convention in presuming that - even though significant cultural differences exist within countries - the nation is still the by far most powerful aggregate force in shaping societal values. Hence, cross-national differences in societal values outsize those attached to inner national cleavages by a large magnitude (Minkov \& Hofstede 2012; Inglehart \& Welzel 2005). Accordingly, I compute cultural value distances between European national populations. To do so I use Welzel's (2013) framework of emancipative and secular values because these two sets of values are indicative of those cross-cultural differences that are most relevant to the countries' economic productivity, regulatory quality and democratic performance. In the context of European integration, cultural convergence may occur via three main mechanisms: (1) a vertical diffusion (trickle down) of values, (2) a horizontal diffusion of values, either directed or undirected (hybridization theory), and (3) convergence in the standard of living.

Institutional isomorphism (Dimaggio \& Powell 1983) and world polity theories (Meyer et al. 1997) form the theoretical foundation for the process of vertical diffusion. Both conceptual frameworks assume the homogenization of institutions, practices and culture toward one or few legitimate references that are perceived as rational and universalistic. The process of becoming similar to one another (isomorphism) operates via three mechanisms: coercion, mimicry and normative isomorphism (Dimaggio \& Powell 1983). The metaphor of newly discovered island societies that quickly acquire all elements and characteristics of contemporary nation states used by Meyer et al. (1997) applies to the southern and eastern European societies that emerged back from totalitarian regimes. The discrediting of communist and other totalitarian ideologies and the lifting of coercive constraints imposed by the Soviet Union in CEE countries left few viable alternatives but a reorientation toward the more prosperous north-western European countries and the restructuring of societies and economies after these role models. The EU assumed an active role and became a transformative authority in these countries.

Some literatures characterize the EU as a value entrepreneur that has developed and seeks to implement a particular image of the ideal European society both among its member states and its candidates (Gerhards 2008, 2010; Gerhards \& Lengfeld 2006; Gerhards et al. 2009). The EU is considered a normative power that upholds and promotes certain political principles and values such as democracy, the rule of law, respect for human rights, peace and tolerance (Manners 2002). Previous studies theoretically and empirically link EU membership to higher 
acceptance of the values embedded in the EU's normative script, including gender equality and sexual liberalism (Gerhards 2010; Gerhards et al. 2009; Zapryanova \& Surzhko-Harned 2016), family and gender roles (Gerhards \& Hoelscher 2003), environmental attitudes (Gerhards \& Lengfeld 2006), acceptance of free movement and nondiscrimination (Gerhards 2008), religious and family values, gender roles, sexuality norms, economic and political values and attitudes toward the welfare state (Gerhards 2007). These values are explicitly implemented in EU legisation. For example, Article 2 of the Treaty on European Union (EU [1992] 2008:17) states that:

The Union is founded on the values of respect for human dignity, freedom, democracy, equality, the rule of law and respect for human rights, including the rights of persons belonging to minorities. These values are common to the Member States in a society in which pluralism, non-discrimination, tolerance, justice, solidarity and equality between women and men prevail.

Compliance with the values described above is regulated in Article 7 of the Treaty for member states, while Article 49 applies to candidate states (Toggenburg \& Grimheden 2016). The conditionality principle means that candidates are obliged to implement the accumulated EU legislation known as the acquis communautaire. However, this is not only a political transformation taking place at the level of elites. EU conditionality and legislative coercion after membership stimulates a much more profound process of societal empowerment (Noutcheva 2016). Political elites in domestic governmental institutions and nongovernmental advocacy networks adopt the normative scripts (and the values they embody) created by EU institutions and spread them via domestic media discourses (Vasilev 2016). Finally, the population at the grassroots level is exposed to the media and thus internalizes these norms and values. With regard to the CEE countries the impact is also long lasting as the incentives offered before membership are later replaced by an "alternative leverage and linkage mechanism, including greater dependence on EU aid and trade and greater exposure to the West for both elites and ordinary citizens" (Levitz \& Pop-Eleches 2010:457).

Furthermore, the EU creates the conditions for a horizontal cultural diffusion to occur between societies, which can be directed or undirected. The four freedoms of movement are among the fundamental principles of the EU-those of goods, workers, services and capital-and compliance with these freedoms entails lifting institutional barriers to close economic and social interactions. European nations presumably blend their cultures under such conditions, thus becoming more similar over time. Cultural and educational initiatives, such as the Erasmus program, have been facilitating cultural exchange among member states for decades. International migration within the EU may have a major impact in terms of both mechanical and ideational cultural blending. After the fall of the Berlin Wall more than 20 million people emigrated from former eastern bloc countries, approximately $85 \%$ of which toward Western Europe and $9 \%$ to the USA (Atoyan et al. 2016). Since they constitute a sizable share of the population of many Western European countries, they also make up a nontrivial fraction of the nationally representative samples of the WVS and EVS, thus adjusting these countries' average scores. Intercultural interactions may also lead to the diffusion of Eastern European migrants' 
cultural traits into local cultures. As members of transnational communities maintaining relationships with their social networks in the sending countries, migrants in Western European countries can also serve as transmitters of cultural values in the opposite direction-back to their country of origin. Theoretical models dealing with the cultural effects of globalization, namely hybridization theory (Holton 2000; Kraidy 2002; Pieterse 1994), argue that societies spread and borrow culture from each other regardless of their standing in terms of economic development, authority and power. Conversely, the mimicry mechanism of isomorphism supposes the presence of a role model, or a normative authority, from which other societies learn - intentionally or unintentionally (Dimaggio \& Powell 1983). Given the high international status and superior standard of living of north-western European countries, it can be assumed that more peripheral societies would be net importers of values and norms.

Bridging differences between national economies could also lead to value convergence. The change to a market economy and the widening of trade opportunities for CEE nations, combined with financial support from the EU, triggered economic growth in the newly accessed and associated states disproportionally to that seen in old member states (Cappelen et al. 2003). "The EU convergence machine" acts as an equalizer of disposable income between the old and new member states (Goedeme \& Collado 2016). As values are strongly dependent on the availability of action resources (Welzel et al. 2003), an equalization of economic development would imply a convergence of values among the EU membership. The mechanisms through which socioeconomic modernization leads to cultural change have been well elaborated and empirically tested in a number of previous studies (e.g., Inglehart \& Baker 2000, Inglehart \& Welzel 2005, Welzel 2013). Therefore, a further analysis of economic modernization would not provide any new insights. Instead, in this analysis I focus on those processes of cultural diffusion that are independent of changes in the economic differences between European states.

\section{Cultural divergence}

Convergence, however, is conditional on the speed of change within each group of countries: the old, new and prospective member states. According to modernization theory, societies change further their values as they develop economically (Inglehart \& Baker 2000), and full compliance with the EU's ideal values is not attained even by the most developed and longterm member states. Therefore, if societies develop culturally in the same direction, the speed of change among the developing new members and the candidates must be faster for a cultural converge to occur. Previous research, however, shows that developed Protestant societies are experiencing swifter cultural change than others (e.g., predominantly Muslim societies), thus leading to divergence over time (Norris \& Inglehart 2002).

Furthermore, studies suggest that "as they diffuse, norms, ideas, and practices often change in form and content," thus the final outcome is not necessarily convergence (Klingler-Vidra \& Schleifer 2014). Focusing on the process of Europeanization, Börzel and Risse (2012) outline four scope conditions that moderate the degree of institutional diffusion: domestic incentives, degrees of (limited) statehood, democracy vs. autocracy and power (a)symmetries. As Western European and former communist states differ on many of those conditions we may expect an 
uneven degree of compliance with official EU norms, which may lead to divergence. Different geopolitical alliances, divergent patterns of cooperation (e.g., trade) within and outside of Europe as well as strong ties to former colonies are other reasons why European nations may take opposing cultural pathways. A crucial factor that can facilitate or impede the transformative impact of the EU is the degree of political elites' identification with the EU (Vasilev 2016). The absence of coercion of nonmembers by the EU allows local authoritarian leaders to instill traditional values through governmentally controlled media channels in pursuit of their own political agendas. Persuasive discourse is likely to have a more profound influence in societies that identify closely with the EU due to their shared historical background. The moral authority of the EU is being challenged decisively by its current geopolitical rival Russia (Headley 2015), whose leaders often outline a distinctive civilizational identity of their nation. By rejecting any notions of moral superiority of the EU and accusing the West of double standards (Headley 2015), Russia creates unfavorable conditions to ideational diffusion within its society. Moreover, the hostility between societies differing in their cultural identity may escalate to, in Huntington's terms, civilizational clashes that are likely to result in reinforcement of traditional local culture and, therefore, to further divergence (Huntington 1996).

\section{Cultural polarization}

Following this discussion it is feasible to assume that both the forces of convergence and divergence can pull European societies in different directions simultaneously, but one of them can prevail over the other in some cases. It is more likely that convergence will occur among EU member states because they are continuously exposed to the normative script of the EU and their shared identity does not act as a boundary to diffusional processes. On the other hand, non-EU members do not share the same institutional framework, and differences in identities may lead to a rejection of the values promoted by Brussels. In this analysis I treat EU membership as an indication of a shared identity among populations or political elites, if there is incongruence, and I hypothesize that this is a decisive dividing force in the cultural development of Europe at large. I expect that the continent is becoming more polarized, with shrinking cultural distance between EU members and growing cultural gaps with nonmembers.

\section{DATA AND METHODS}

\section{Sample definition}

The focus of this analysis is Europe in its largest conceivable form, which includes all countries that are at least partly located on the continent or were part of the former Soviet Union. The reason for including some Central Asian ex-Soviet republics is that they are connected to Europe culturally and geopolitically. For example, Azerbaijan, Armenia and Georgia participate in the Eastern European partnership with the EU and are considered potential candidates for EU membership. 


\section{Data}

The greatest challenge for this analysis was to create a dataset that consists of a large number of European countries that were surveyed consistently with the same items over the same period of time. To construct the dataset I combined all survey waves of the EVS and WVS, which cover the period between 1981 and 2014. Each of the four EVS and six WVS waves consists of nationally representative surveys of typically between 1000 to 2000 respondents in between 10 to 57 nations around the world.

In order to maximize the sample size at the country-year level without having to make strong assumptions about value trends over long time periods, I linearly interpolated the data of my selected value-related items only for the years between any two conducted surveys. That means I did not extrapolate data before the first or after the last survey measurement ${ }^{1}$ as we cannot be certain about the direction of the trend unless we make a strong assumption that it is a function of other societal characteristics for which data are available (for a similar procedure, see Spaiser et al. 2014). Thus for most countries the data for the specific year used in the analysis were either from an actual survey or from within a few years of one. For a detailed description of the survey years and the interpolated data for each country, see Figure S1 in the appendix.

In order to assess the change over time I compare exactly the same countries at the beginning and the end of a specified period. As there is a tradeoff between the number of countries and the time coverage, I use four different datasets. For a cross-sectional analysis as of 2008 (Figure 1) I use data for 48 European countries. The longest longitudinal dataset consists of 29 European countries (17 Western European, 11 ex-communist and Turkey) followed up for 17 years, from 1992 to 2008. Since none of the candidate countries were surveyed as early as 1992 except for Turkey, I conducted an additional analysis for the period between 2001 and 2008 encompassing 43 nations. Lastly I analyzed the change of values between 2008 and 2011 with a smaller dataset of 17 European countries. Consistent data before 1990 are available only for a handful of Western European countries, which prevents any robust analysis of cultural change before the fall of the Berlin Wall.

\section{Operationalization of variables}

The dependent variable is a formative additive index of value distance based on Welzel's (2013) two value dimensions: obedient-emancipative (in short emancipative values) and sacred-secular (in short secular values). The emancipative value index consists of four components (subindices): autonomy, equality, choice and voice. It emphasizes both freedom of choice and equality of opportunity (Welzel 2013). The secular value index, also consisting of four subindices, namely defiance, agnosticism, relativism and skepticism, describes the level of dissociation from external, quasi-sacred sources of authority such as religion, the nation and group norms (Welzel 2013). As values are the central and most fundamental elements of culture

\footnotetext{
${ }^{1}$ The only exception is Romania, which was first surveyed in 1993, but the entry was changed to 1992 in order to increase the dataset with one more country.
} 
(Hofstede 1991; Schwartz 2006), these indices intend to measure culture in a more general sense. I thus use "values," "cultural values" and "culture" interchangeably throughout the text.

Aléman and Woods (2016) have raised concerns regarding the internal convergence of these value indices at the individual level, yet at the aggregate level, as it is used in this analysis, external linkage validates the constructs as a powerful explanation for a wide range of social phenomena (Welzel \& Inglehart 2016). Aggregate-level national culture has been shown to be a meaningful analytical concept (Minkov \& Hofstede 2012) and European countries demonstrate a high level of cultural homogeneity when regional differences within countries are considered (Minkov \& Hofstede 2014).

I computed value indices following the instructions in Welzel's (2013) online appendix and adapted them to a dyadic analysis with repeated cross-sectional data. Two of the items for the equality, voice and defiance subindices were not asked consistently in each survey year, and these components were computed based on only one item as a result. However, each component was nevertheless weighted equally in the computation of the two indices. The total value distance between pairs of countries (dyads), used as the dependent variable in this analysis, is the average combined distance on the emancipative and secular value indices. ${ }^{2}$ The maximum possible distance in a dyad is 1.0 and the minimum is 0 . These hypothetical scale endpoints are empirically implausible, however, because reaching them would mean that all individual respondents in two nations would have to take either exactly the same or exactly opposite positions on a total of 20 survey items. For summary statistics of the dependent variable for each data set, see Table 1 .

Table 1 Description of datasets and summary statistics of dependent variable

\begin{tabular}{lcccc}
\hline Dataset & $1992-2008$ & $2001-2008$ & 2008 & $2008-2011$ \\
\hline Number of years & 17 & 8 & 1 & 4 \\
Number of time points & 2 & 2 & 1 & 2 \\
Number of dyads at each time point & 406 & 903 & 1128 & 136 \\
Number of countries & 29 & 43 & 48 & 17 \\
Number of current EU members & 24 & 28 & 28 & 9 \\
Mean value distance & .139 & .146 & .154 & .185 \\
Standard deviation between & .082 & .085 & .093 & .106 \\
Standard deviation within & .033 & .024 & N/A & .024 \\
Min & .000 & .002 & .002 & .006 \\
Max & .506 & .506 & .506 & .511 \\
\hline
\end{tabular}

Formal membership in the EU and official candidacy status are the key explanatory variables for this analysis. Data were obtained from the official website of the European Union in 2016.

\footnotetext{
${ }^{2}$ Alternatively, the distances were computed as the average distances on each of the individual items and also as the average distances on each of the eight sub-indices, which relaxes the assumptions about the internal structure of the value indices - this did not change the findings of the analysis qualitatively.
} 
Member states were categorized following a conventionally used classification into (1) founding states, (2) old member states that joined the EU before 1996, (3) new member states that joined between 2004 and 2013, (4) Schengen area non-EU nations, (5) official candidates and (6) noncandidates. I place Schengen area non-EU nations in a separate category because they are qualitatively different from other nonmembers due to their participation in free movement.

Difference in the level of economic development was measured as the ratio of GDP per capita between two countries, that is the GDP/capita of the country with the smaller GDP/capita divided by that of the county with the higher GDP/capita. Data on Estonia, Latvia and Slovenia were not available before 1995, but in order to include these countries in the analysis I assumed that they did not change their economic output between 1992 and 1995. This is a reasonable assumption considering the economic stagnation during this period.

\section{Methods}

I use undirected dyadic data OLS regressions in order to assess the cultural distances between European nations and how these distances change over time. This means that all units of analysis are unique pairs of countries, and the variables denote how (dis)similar the pairs are with regard to their values and economic development, as well as whether they have any attributes in common such as being founding members of the EU. This method offers the possibility of computing and assessing the total cultural distance between nations, including both cultural dimensions, in order to test the hypotheses for convergence and divergence. This comes at the expense of information on the direction of change in cultural distance. We are able to assess whether the distance has become smaller or larger, but we need an additional analysis in order to conclude how countries changed their value priorities. In dyadic data, countries will appear multiple times within country pairs, for example Austria-Belgium, Austria-Belarus, Belgium-Belarus and so on, which leads to a correlation of error terms (Aronow et al. 2015). I correct this by computing two-way cluster-robust standard errors, which is one of the common approaches to addressing this problem (Cameron et al. 2011).

I also analyze change in cultural distances within and between groups of countries in (dyadic) fixed-effects regression (Alison 2009) based on their membership status. As values change slowly, I focus on the cumulative change from the beginning of the period to the end. Comparing the change in cultural distance between EU founders on the one hand and new members versus nonmembers on the other is similar to the difference-in-difference approach. This is the case even though the treatment, namely joining the EU, cannot be regarded as randomly assigned. I use the same approach with countries that have commenced negotiations with the EU as with those that have not. I also compare the change in average value distances among and between countries that did not change their membership status by using interaction terms between a categorical variable denoting groups of countries based on their status on one hand and the time variable on the other. Thus I am able to estimate the long-term change associated with EU membership compared to changes occurring in countries not participating in European integration. 


\section{Causality considerations}

The analysis relies on identifying both cross-sectional and temporal patterns in order to draw conclusions about any possible influence of the EU on cultural similarities among countries. Since data before 1992 are very limited we are unable to assess the role of the EU during the earlier stages of integration. Identifying cross-sectional difference based on EU membership might be indicative of a causal effect, but other sources of association, including a reverse causality, cannot be excluded. Reverse causality would mean that nations having more similar values because of their common historical background and similar level of economic development formed the EU and further enlargements are based on cultural compatibility, whether that is real or perceived.

The question of causality can hardly be solved conclusively in the absence of experimental control. and such an endeavor at the scale of nations is conceivably impossible. An association between European integration (A) and cultural similarity (B) can emerge from three different mechanisms: (1) A causes B, (2) B causes A or (3) a third variable C causes both A and B (Dietz \& Kalof 2009).

Using longitudinal data allows the exclusion of possibilities 2 and 3 with some degree of confidence. Reverse causality (possibility 2) can be rejected in two cases: first, if cultural convergence occurs among member states but not among nonmember states, and second, if those countries that joined the EU were initially no more similar to core EU countries than nonmembers but converged culturally through integration. The problem of omitted variables can also be better addressed through longitudinal data (Alison 2009). Similarities with regard to national characteristics such as population, spoken language, predominant religion, historical background, climate and geographic location, which are strongly associated with value similarities (Akaliyski 2017), are fixed or relatively stable. They can explain cross-sectional patterns of value distances quite well, but not changes in cultural distances. These are more likely to occur as a result of changes over time in other characteristics such as EU membership and economic development.

Convergence in the standards of living may well be another outcome of EU integration, thus serving as a mechanism that stands on the causal pathway between European integration and cultural convergence. However, this convergence may also be completely independent of EU integration and therefore constitute a spurious relationship. As a result, by controlling for the change in GDP/capita differences I exclude the most likely alternative explanation for any changes in cultural distances, even if that may lead to attenuation of the real effect by overcontrolling. If there were in fact a strict temporal order and adequate controls for alternative explanations then it would be plausible to assume that any associations are causal. Other sources of endogeneity, however, cannot be completely ruled out. Cultural exchange, economic and political cooperation and migration are not just European but also global processes. Consequently, the consolidation of values among EU countries may not necessarily be driven only by ideals emanating from Brussels, but could also proceed following an emerging global cultural script that finds more support among liberal Western democracies (Deutsch \& Welzel 
2016). However, this argument is undermined by the fact that most cultural frameworks depict Europe as the leader in cultural change, followed by (English-speaking) non-European Western societies.

Apparently there is also a geographic pattern: Newly accessed member states are geographically closer to old members than those that remain outside; therefore, one can argue that any convergence is due to geographic proximity instead of EU membership. This explanation, however, does not contradict the theoretical argument made in this article, namely that the change in cultural values can largely be attributed to the ideational diffusion across borders. The CEE countries have not changed their geographical location since 1991 but what changed was their geopolitical orientation. Some nations turned decisively toward Brussels, while others had different priorities on their agendas. The Western Balkan countries, for example, are geographically closer to the rest of the EU, but the Eastern Balkan nations of Bulgaria and Romania were more successful in joining the EU.

\section{RESULTS}

The results section is divided into five parts. The first part examines the cross-sectional patterns of value distances by comparing the average cultural distance between groups of countries. The second, third and fourth parts provide formal tests of the differences in cultural distance between groups of countries with the use of dyadic regressions as well as analysis of the change over time. The second part focuses on the cultural patterns between old and new member states, the third part extends the scope to candidate states while the fourth part looks at cultural changes over a more recent time period. The last part identifies the direction of cultural change in order to conclude by affirming a specific theoretical perspective.

\section{EU membership and value similarities in 2008}

A comparison of average value distance between groups of EU members is presented in Figure 1. Evidently the founders of the EU are the most homogenous group with an average value distance of .078. Adding other groups of countries increases the cultural heterogeneity respective to their level of integration into the EU. The average cultural diversity is around $30 \%$ larger among old members than among the founders, and it increases by $42 \%$ if we include the eastern enlargements. The value heterogeneity in the EU in 2008 could have increased by $56 \%$ if the current candidates had become members, but that is still less than the total value heterogeneity for Europe, which is nearly two times larger than the average for EU founders. The inclusion of the three non-EU Schengen area members (Norway, Iceland and Switzerland) would not lead to a significant increase in cultural diversity. The Eurasian Union (EAU), consisting of only five member states, demonstrates a similar level of cultural homogeneity to that of the old EU members. 
Figure 1 Average value distance by EU/EAU integration in 2008 for 48 European nations with $95 \%$ confidence intervals

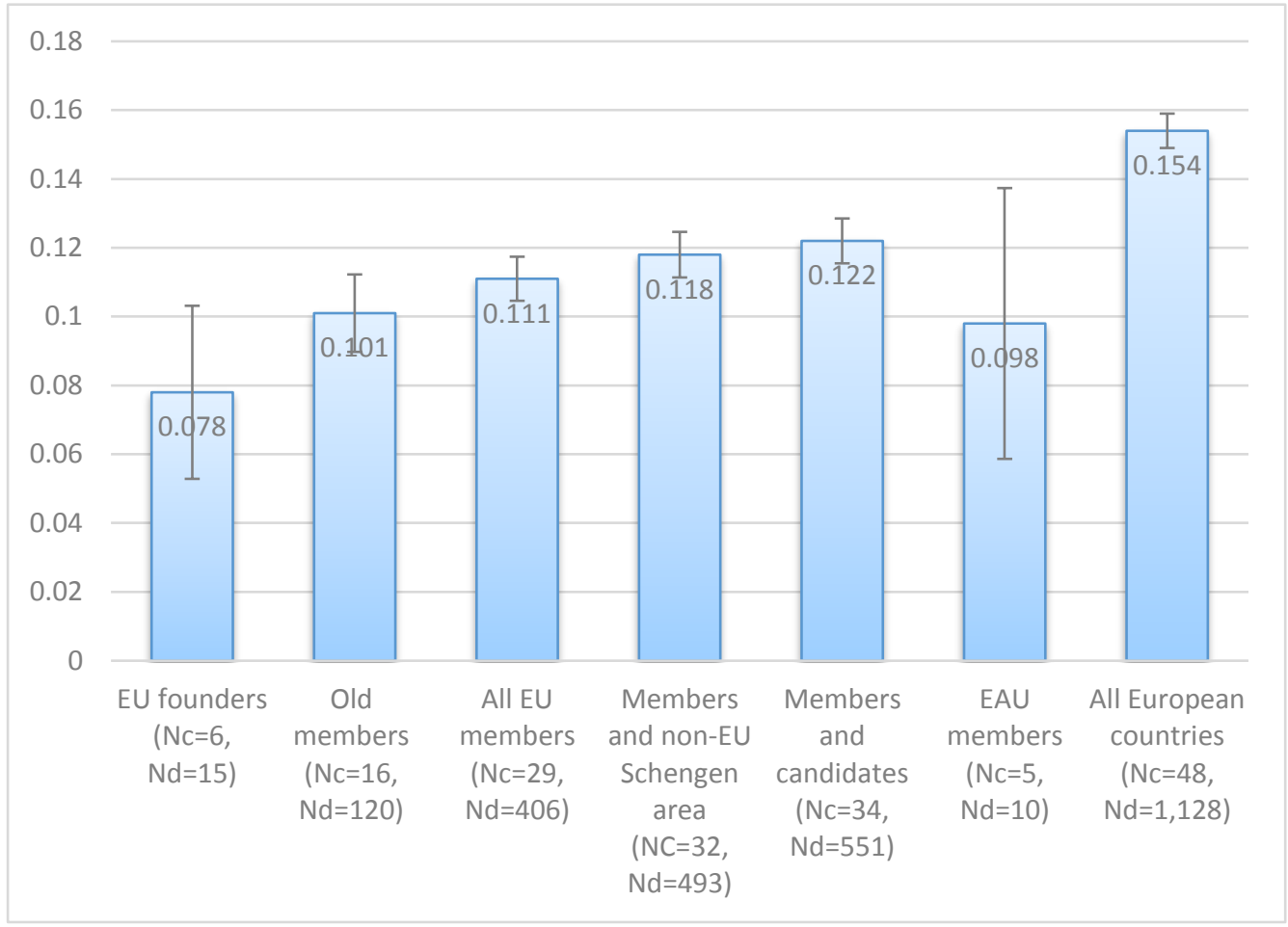

Notes: $\mathrm{Nc}=$ number of countries, $\mathrm{Nd}=$ number of dyads. $\mathrm{UK}$ is split between Great Britain and Northern Ireland.

\section{Development over time (1992-2008)}

The cross-sectional patterns in 2008, presented above, suggest a linear relationship between the degree of involvement with the EU and cultural homogeneity. By moving to a longitudinal design, I will now attempt to conclude between two viable possibilities: (1) countries that are similar to each other initiated the EU and consecutive enlargements were based on value compatibility and (2) EU integration is associated with value convergence regardless of the original cultural distance. Figure 2 provides evidence in favor of the latter interpretation. In 1992 the average value distance between current EU members was practically the same as the distance between member states and nonmember states, as well as the average among all European countries. As the $\mathrm{R}^{2}$ of the model shows, EU membership does not explain any variability in cultural distances in Europe immediately after the fall of the Berlin Wall. Members and nonmembers seemed to take different paths of cultural development-EU members toward convergence and nonmembers in the opposite direction. Between 1992 and 2008 the cultural distance between EU members decreased by $22 \%$ (.024), while during the same period the distance between EU members and nonmembers increased by $67 \%$ (-.063 points or nearly 2 SDs-within). As those two opposing tendencies cancel each other out, the average value differences for the whole sample remains virtually unchanged between 1992 and 2008. In reality, however, the continent has become more fragmented culturally. 
Figure 2 Change in average value distance by EU membership between 1992 and 2008 with $95 \%$ confidence intervals

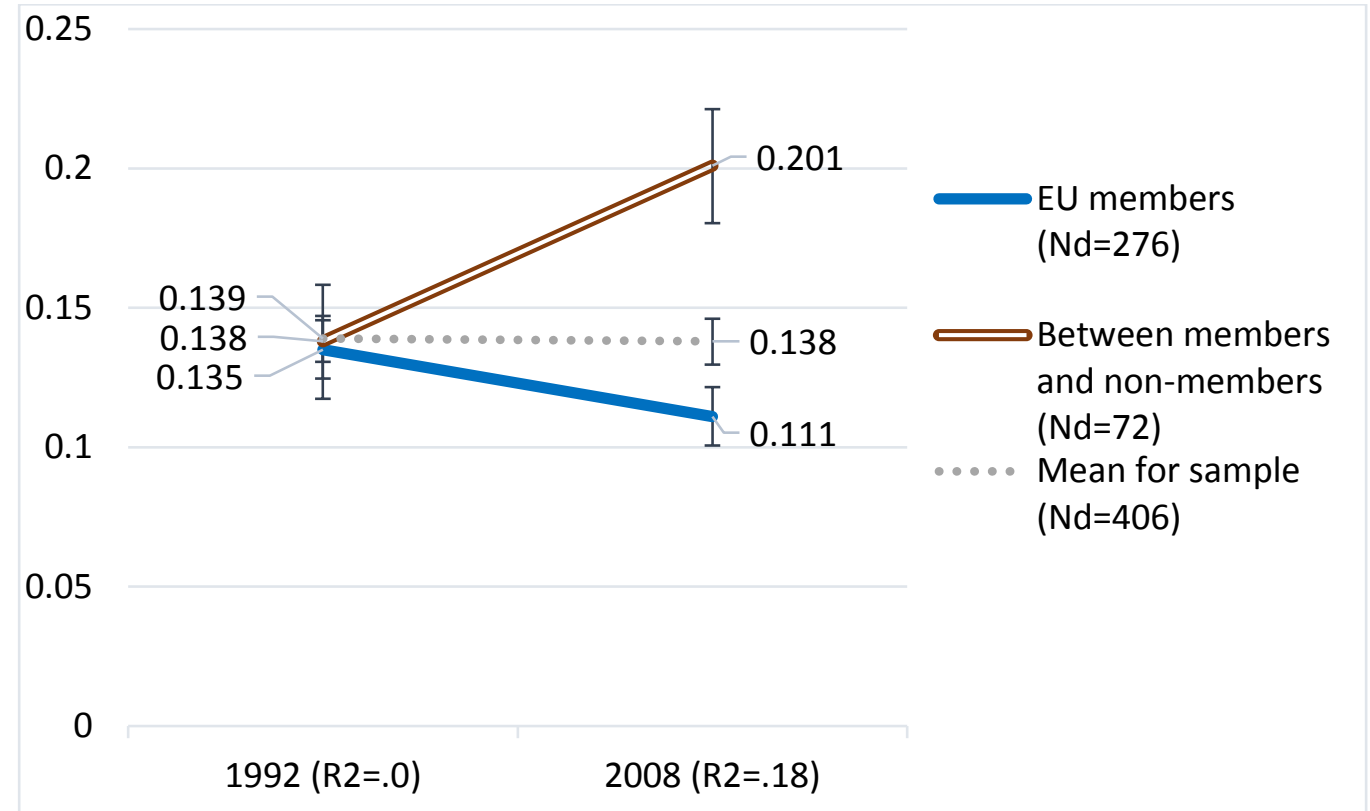

Notes: $\mathrm{Nd}=$ number of dyads. EU membership is as of 2016. Non-EU members do not include Schengen area nations.

Further evidence for the role of the EU in consolidating cultural values is presented in Table 2. Model I and II display estimated margins of average cultural distances (similar to raw scores) first between the founders and then between the founders and groups of countries with different relationships to the EU. The founders appear most homogenous, and distances increase to those groups of countries that are to a lesser degree associated with the EU. This pattern remains similar when controlling for GDP/capita differences. A notable finding is that new members (which were not yet candidates at that time) and current nonmembers are approximately equidistant from the EU founders, even after controlling for differences in GDP/capita. This implies that cultural compatibility is not a criterion for initiating negotiations for membership, as might be counterargued.

Model III presents results from a dyad fixed-effects regression that takes into account only the change over time, with 1992 and 2008 as the two selected time points. During this time period the cultural distance between the founders and both the old and new members was reduced significantly and substantially. Meanwhile the cultural gap between EU founders and nonmembers increased by .066 points (which is exactly 2 SDs). Significant cultural disintegration was also experienced among the founders and the non-EU Schengen area members, as well as among the three nonmembers in the dataset. Most of the coefficients become even stronger in Model IV, where I control for the change in the differences in GDP/capita. Furthermore, I repeated these analyses with emancipative and secular values separately to demonstrate that the same patterns can be identified with regard to both value dimensions (the results are presented in Tables S2.A and S2.B in the appendix). 
Table 2 Total dyadic value distance regressed on EU membership and change from 1992 to 2008

\begin{tabular}{|c|c|c|c|c|c|c|}
\hline \multirow[b]{2}{*}{ Group of countries } & \multicolumn{2}{|c|}{$\begin{array}{c}\text { Average value distance } \\
\text { (estimated margins from OLS) }\end{array}$} & \multicolumn{2}{|c|}{$\begin{array}{l}\text { Change in average value distance } \\
\text { (unstandardized coeff. from FE) }\end{array}$} & \multirow{2}{*}{$\begin{array}{c}\text { Number of } \\
\text { dyads in } \\
\text { group }\end{array}$} & \multirow{2}{*}{$\begin{array}{c}\text { Number of } \\
\text { countries } \\
\text { in group }\end{array}$} \\
\hline & $\begin{array}{c}\text { Model I } \\
1992\end{array}$ & $\begin{array}{c}\text { Model II } \\
1992\end{array}$ & $\begin{array}{c}\text { Model III } \\
1992-2008\end{array}$ & $\begin{array}{l}\text { Model IV } \\
1992-2008\end{array}$ & & \\
\hline $\begin{array}{l}\text { Among EU founders (ref. for Models I } \\
\text { and II) }\end{array}$ & $\begin{array}{c}.089 \\
(.014)\end{array}$ & $\begin{array}{c}.054 \\
(.035)\end{array}$ & $\begin{array}{l}-.001 \\
(.016)\end{array}$ & $\begin{array}{c}.006 \\
(.017)\end{array}$ & 10 & 5 \\
\hline Founders and old members & $\begin{array}{c}.117 \\
(.008)\end{array}$ & $\begin{array}{l}.095+ \\
(.021)\end{array}$ & $\begin{array}{l}-.016^{*} \\
(.007)\end{array}$ & $\begin{array}{r}-.019^{*} \\
(.008)\end{array}$ & 45 & 14 \\
\hline Founders and new members & $\begin{array}{l}.128 * \\
(.013)\end{array}$ & $\begin{array}{c}.152 \\
(.030)\end{array}$ & $\begin{array}{c}-.029 * * \\
(.007)\end{array}$ & $\begin{array}{c}-.047 * * \\
(.011)\end{array}$ & 50 & 15 \\
\hline Founders and Schengen area & $\begin{array}{c}.124 \\
(.019)\end{array}$ & $\begin{array}{l}.097+ \\
(.031)\end{array}$ & $\begin{array}{l}.042 * \\
(.016)\end{array}$ & $\begin{array}{l}.057 * * \\
(.018)\end{array}$ & 10 & 7 \\
\hline Founders and nonmembers & $\begin{array}{l}.136+ \\
(.020)\end{array}$ & $\begin{array}{l}.165+ \\
(.033)\end{array}$ & $\begin{array}{l}.066^{* *} \\
(.013)\end{array}$ & $\begin{array}{l}.057 * * \\
(.014)\end{array}$ & 15 & 8 \\
\hline Among nonmembers & $\begin{array}{c}.113 \\
(.035)\end{array}$ & $\begin{array}{c}.098 \\
(.036)\end{array}$ & $\begin{array}{l}.058+ \\
(.030)\end{array}$ & $\begin{array}{l}.057+ \\
(.030)\end{array}$ & 3 & 3 \\
\hline Control for GDP/capita & No & Yes & No & Yes & Total: 133 & Total: 29 \\
\hline $\mathrm{R}^{2}$ & .02 & .04 & & & & \\
\hline $\mathrm{R}^{2}$ (within) & & & .29 & .31 & & \\
\hline
\end{tabular}

Notes: Two-way cluster-robust standard errors in parentheses. $* * p<0.01,{ }^{*} \mathrm{p}<0.05+\mathrm{p}<0.1$. Significance tests in model I and II refers to the difference compared to the reference category. In model III and IV, it shows whether the change over time within this group of countries is statistically significant. OLS - ordinary least-squared regression. FE - fixed-effects regression. The groups of countries include only dyads where one country belongs to the first groups and the other to the second group. E.g., "Founders and old members" includes pairs of one founder and one old member but not two founders or two old members.

EU memberships is as of 2016. Non-EU members exclude non-EU Schengen area countries. EU Founders: Belgium, France, Germany, Italy and Netherlands. Old Members: Austria, Denmark, Finland, Ireland, Portugal, Spain, Sweden and Great Britain. Schengen area (non-EU): Iceland and Norway. New members: Bulgaria, Czechia, Estonia, Hungary, Latvia, Malta, Poland, Romania, Slovakia and Slovenia. Nonmembers (excluding non-EU Schengen area): Belarus, Russia and Turkey. 


\section{Candidates and noncandidates: cultural change between 2001 and 2008}

Next I explore whether EU integration is associated with cultural convergence even before formal membership. Models I and II shown in Table 3 present results using the old EU members as the reference category in order to increase the number of cases for the comparisons. Within this sample the distances between old member states on the one hand and candidates and noncandidates on the other are of approximately the same magnitude, both without and with control for GDP/capita differences. This indicates again that the conditionality to commence negotiations for accession does not include initial cultural similarity. Model III reveals similar patterns of temporal development to those shown in Table 2. The newly accepted member states significantly minimized the cultural gap that existed between them and the old members during the short period of eight years by more than a whole SD-within. The most compelling findings in the table is that the official EU candidates significantly shortened their value distance to old members by more than one and a half SDs, while during the same period noncandidates diverged slightly (marginally statistically significant). The rate of convergence becomes even larger when controlling for GDP/capita ratio in Model IV. Again, I repeated these analyses for the two value dimensions separately (Tables S3.A and S3.B) and I found that the patterns were similar. However, they are much more pronounced and consistent with respect to emancipative values.

\section{Cultural change after 2008}

In Table 4 I explore whether these processes continued during the financial crisis after 2008. Even though the data are too limited to make firm conclusions, there is no evidence that the old and new members disintegrated culturally. Concurrently to this development nonmembers continued to diverge with a remarkable pace during a four-year period. Even though I used different samples in each of the analyses it should be noted that the $\mathrm{R}^{2}$ for the unadjusted model in Table 4 is .61 compared to .26 for the model in 2001 and .02 for 1992 . This may serve as evidence that the deepening of the European integration has been a cause for significant cultural differences in Europe to emerge since the early 1990s. 
Table 3 Total dyadic value distance regressed on EU membership and change from 2001 to 2008

\begin{tabular}{|c|c|c|c|c|c|c|}
\hline \multirow[b]{2}{*}{ Group of countries } & \multicolumn{2}{|c|}{$\begin{array}{c}\text { Average value distance } \\
\text { (estimated margins from OLS) }\end{array}$} & \multicolumn{2}{|c|}{$\begin{array}{c}\text { Change in average value } \\
\text { distance (unstandardized coeff. } \\
\text { from FE) }\end{array}$} & \multirow[t]{2}{*}{$\begin{array}{l}\text { Number of } \\
\text { dyads in } \\
\text { group }\end{array}$} & \multirow{2}{*}{$\begin{array}{l}\text { Number } \\
\text { of } \\
\text { countries } \\
\text { in group }\end{array}$} \\
\hline & $\begin{array}{l}\text { Model I } \\
2001\end{array}$ & $\begin{array}{l}\text { Model II } \\
2001\end{array}$ & $\begin{array}{l}\text { Model III } \\
2001-2008\end{array}$ & $\begin{array}{l}\text { Model IV } \\
2001-2008\end{array}$ & & \\
\hline $\begin{array}{l}\text { Among Old EU members (ref. for } \\
\text { Models I and II) }\end{array}$ & $\begin{array}{c}.097 \\
(.005)\end{array}$ & $\begin{array}{c}.098 \\
(.011)\end{array}$ & $\begin{array}{c}.003 \\
(.003)\end{array}$ & $\begin{array}{c}.003 \\
(.003)\end{array}$ & 119 & 16 \\
\hline $\begin{array}{l}\text { Old EU members and new } \\
\text { members }\end{array}$ & $\begin{array}{l}.137 * * \\
(.006)\end{array}$ & $\begin{array}{l}.137 * * \\
(.006)\end{array}$ & $\begin{array}{c}-.027 * * \\
(.003)\end{array}$ & $\begin{array}{c}-.037 * * \\
(.004)\end{array}$ & 176 & 27 \\
\hline Old EU members and candidates & $\begin{array}{l}.218^{* * *} \\
(.010)\end{array}$ & $\begin{array}{l}.217 * * \\
(.012)\end{array}$ & $\begin{array}{c}-.038 * * \\
(.005)\end{array}$ & $\begin{array}{c}-.043 * * \\
(.005)\end{array}$ & 64 & 20 \\
\hline $\begin{array}{l}\text { Old EU members and } \\
\text { noncandidates }\end{array}$ & $\begin{array}{l}.204 * * \\
(.006)\end{array}$ & $\begin{array}{l}.204 * * \\
(.009)\end{array}$ & $\begin{array}{l}.007+ \\
(.003)\end{array}$ & $\begin{array}{c}.001 \\
(.004)\end{array}$ & 128 & 25 \\
\hline $\begin{array}{l}\text { Among non-members } \\
\text { (noncandidates) }\end{array}$ & $\begin{array}{c}.100 \\
(.009)\end{array}$ & $\begin{array}{l}.101 \\
(.011)\end{array}$ & $\begin{array}{l}-.003 \\
(.008)\end{array}$ & $\begin{array}{l}-.002 \\
(.008)\end{array}$ & 28 & 8 \\
\hline $\begin{array}{l}\text { Control for GDP/capita } \\
\mathrm{R}^{2} \\
\mathrm{R}^{2} \text { (within) }\end{array}$ & $\begin{array}{l}\text { No } \\
.26\end{array}$ & $\begin{array}{l}\text { Yes } \\
.26\end{array}$ & No & Yes & Total: 515 & Total: 39 \\
\hline
\end{tabular}

Notes: Two-way cluster-robust standard errors in parentheses. $* * \mathrm{p}<0.01, * \mathrm{p}<0.05+\mathrm{p}<0.1$. Significance tests in model I and II refers to the difference compared to the reference category. In model III and IV it shows whether the change over time within this group of countries is statistically significant. OLS - ordinary least-squared regression. FE - fixed-effects regression. The groups of countries include only dyads where one country belongs to the first groups and the other to the second group.

Old EU members: Austria, Belgium, Denmark, Finland, France, Germany, Greece, Ireland, Italy, Luxembourg, Netherlands, Spain and Sweden. New members: Bulgaria, Croatia, Czechia, Estonia, Hungary, Latvia, Lithuania, Malta, Poland, Romania, Slovakia and Slovenia. Candidates: Albania, Montenegro, Serbia and Turkey. Noncandidates: Azerbaijan, Armenia, Bosnia and Herzegovina, Belarus, Georgia, Moldova, Russia and Ukraine. 
Table 4 Dyadic distance in total value distance regressed on EU membership and change from 2008 to 2011

\begin{tabular}{|c|c|c|c|c|c|c|}
\hline \multirow[b]{2}{*}{ Group of countries } & \multicolumn{2}{|c|}{$\begin{array}{c}\text { Average value distance } \\
\text { (estimated margins from OLS) }\end{array}$} & \multicolumn{2}{|c|}{$\begin{array}{l}\text { Change in average value distance } \\
\text { (unstandardized coeff. from FE) }\end{array}$} & \multirow{2}{*}{$\begin{array}{l}\text { Number } \\
\text { of dyads } \\
\text { in group }\end{array}$} & \multirow{2}{*}{$\begin{array}{c}\text { Number } \\
\text { of } \\
\text { countries } \\
\text { in group }\end{array}$} \\
\hline & $\begin{array}{l}\text { Model I } \\
2008\end{array}$ & $\begin{array}{l}\text { Model II } \\
2008\end{array}$ & $\begin{array}{c}\text { Model III } \\
2008-2011\end{array}$ & $\begin{array}{l}\text { Model IV } \\
2008-2011\end{array}$ & & \\
\hline $\begin{array}{l}\text { Among old EU members (ref. for } \\
\text { Models I and II) }\end{array}$ & $\begin{array}{l}.105 \\
(.026)\end{array}$ & $\begin{array}{c}.085 \\
(.032)\end{array}$ & $\begin{array}{l}-.017 \\
(.017)\end{array}$ & $\begin{array}{l}-.010 \\
(.017)\end{array}$ & 6 & 4 \\
\hline $\begin{array}{l}\text { Old EU members and new } \\
\text { members }\end{array}$ & $\begin{array}{l}.174 * \\
(.023)\end{array}$ & $\begin{array}{l}.170 * \\
(.023)\end{array}$ & $\begin{array}{l}-.000 \\
(.009)\end{array}$ & $\begin{array}{c}.001 \\
(.009)\end{array}$ & 20 & 9 \\
\hline $\begin{array}{l}\text { Old EU members and } \\
\text { nonmembers }\end{array}$ & $\begin{array}{l}.286 * * \\
(.017)\end{array}$ & $\begin{array}{l}.298 * * \\
(.022)\end{array}$ & $\begin{array}{l}.030 * * \\
(.007)\end{array}$ & $\begin{array}{l}.028 * * \\
(.007)\end{array}$ & 32 & 12 \\
\hline Among nonmembers & $\begin{array}{c}.115 \\
(.011)\end{array}$ & $\begin{array}{l}.109 \\
(.011)\end{array}$ & $\begin{array}{c}.000 \\
(.007)\end{array}$ & $\begin{array}{c}.002 \\
(.007)\end{array}$ & 28 & 8 \\
\hline Control for GDP/capita & No & Yes & No & Yes & Total: 86 & Total: 17 \\
\hline $\mathrm{R}^{2}$ & .61 & .45 & & & & \\
\hline $\mathrm{R}^{2}$ (within) & & & .18 & .21 & & \\
\hline
\end{tabular}

Notes: Two-way cluster-robust standard errors in parentheses. $* * p<0.01, * p<0.05+p<0.1$. Significance tests in model I and II refer to the difference compared to the reference category. In model III and IV it shows whether the change over time within this group of countries is statistically significant. OLS - ordinary least-squared regression. FE - fixed-effects regression. The groups of countries include only dyads where one country belongs to the first groups and the other to the second group.

Old EU members: Germany, Netherlands, Spain and Sweden. New members: Cyprus, Estonia, Poland, Romania and Slovenia. Nonmembers: Azerbaijan, Armenia, Belarus, Georgia, Kyrgyzstan, Russia, Turkey and Ukraine. Among the group of nonmembers, only Turkey is an official candidate for EU membership. 


\section{Direction of convergence}

An additional analysis explores the direction of convergence between the old and new member states in order to shed light on the comparative relevance of world-polity and hybridization theories. Table 5 demonstrates a clear pattern of convergence from the new member states to the old ones. When the values of the old member states were held constant at year 1992, the cultural distance decreased by .035 points as a result of the change in values occurring in new member states between 1992 and 2008, which is larger than the actual rate of convergence (.029). Conversely, when the values of the new member states were fixed at their 1992 levels, the two groups of countries increased their value distance by .049 points. These findings support the notion that the EU is a normative authority, which implies the borrowing of cultural values by new member states. This is in line with world-polity theory rather than mutual cultural influence as suggested by hybridization theory.

Table 5 Direction of convergence between old and new member states from 1992 to 2008

\begin{tabular}{lccc}
\hline Change in value distance: & Coefficient & S.E. & $\mathrm{R}^{2}$ \\
\hline Between old and new member states & $-.029^{* *}$ & .004 & .22 \\
$\begin{array}{l}\text { From new toward old members (holding old members' values } \\
\text { constant at 1992) }\end{array}$ & $-.035^{* *}$ & .007 & .14 \\
$\begin{array}{l}\text { From old toward new members (holding new members' values } \\
\text { constant at 1992) }\end{array}$ & $.049^{* *}$ & .003 & .60 \\
\hline
\end{tabular}

Note: Number of dyads $=140$. New member states are those that joined the EU after 1995 .

\section{DISCUSSION}

In this paper I analyze data sets on cultural outcomes based on nationally representative data sets comprising a large number of European countries and collected over a 20 -year period in order to assess the cultural outcomes of European integration. A first finding is that there exists a linear relationship between years of shared EU membership and value similarity in 2008 . The founders of the EU are the most homogenous culturally and the distance between them and the old member states is smaller than between the new member states, while the distance to nonmembers is the greatest. This deepens the previous finding that EU membership explains part of the variation in cultural distances in Europe (Akaliyski 2017).

Second, cultural homogeneity within the EU increased primarily between 1992 and 2008. This provides empirical evidence that the third wave of European integration - a cultural one-is already underway (Lahdesmaki 2016), regardless of whether this is the result of efforts of EU institutions or simply a by-product of integration in other spheres.

Third, the direction of convergence is clearly from new member states toward old member states, which supports the notion of a vertical process of diffusion based on world-polity (Meyer et al. 1997) and institutional isomorphism theories (Dimaggio \& Powell 1983), as well as 
directional cultural diffusion. One possibility is that the old members dominate the discourse in EU institutions, which is why cultural scripts trickle down vertically into the populations of new member states. However, another possibility is that diffusion happens horizontally: Populations in new member states may consider those in the old ones role models. As a result, signal flow via the media and other channels is more extensive from old to new member states, which explains the direction of convergence. This finding does not favor hybridization theory, which would suppose a convergence toward a middle ground. Nevertheless, some cultural influence may go in the opposite direction, too-not least mechanically through large-scale migration from Eastern to Western Europe, but is clearly outweighed by cultural influence in the opposite direction. Hybridization may also be more applicable regarding the homogenization of values in old member states, where cultural authority is not as clearly defined. The second and third findings also favor the concept of Europe as a value entrepreneur that promotes a certain cultural script among its member states (Gerhards 2008, 2010; Gerhards \& Lengfeld 2006; Gerhards et al. 2009).

Fourth, in 1992 the new member states were as culturally distant to the EU founders as the nonmembers were. As this occurred only a few years before most CEE countries began negotiations for membership, we can conclude that initial cultural compatibility with the core of the EU cannot be regarded as a condition for becoming a member (although exceptions may exist). The process of integration could be the cause for the observed cultural shift toward Western Europe, in contrast to the countries that did not take the "road to Brussels" at that time.

Fifth, the current candidates for EU membership were no more culturally similar to the old members in 2001 than the countries that have not yet started negotiations or applied for membership were. This again points to the irrelevance of initial cultural compatibility both for beginning the process of integration and for actual membership. Their foreign political orientation toward the EU, however, could be the reason for the observed cultural convergence with old members between 2001 and 2008 even without being formal EU members yet.

Sixth, in contrast to the new members and candidates, countries that remain outside the integration process as of 2017 experienced a considerable divergence from EU nations. This confirms that differences in identities, namely the lack of orientation toward the EU, can hinder cultural diffusion (Vasilev 2016) and lead to cultural development in the opposite direction (Headley 2015).

Seventh, the above findings remain robust when controlling for differences at the level of economic development. This speaks not only of independence of the association between membership status and cultural similarities but also indicates that the differences in wealth between nations and change experienced by them cannot be regarded as the mechanism that explains these patterns of convergence and divergence.

Each of these findings is in itself compelling, but taken together they provide robust evidence that the EU has undergone a process of cultural integration among member states and of differentiation from the rest of Europe. That is, the European continent is not becoming more 
homogenous overall but more polarized between EU members and countries that aspire to membership on the one hand and those that remain unaffiliated on the other. This approximates Huntington's interpretation of cultural grouping into distinct civilizations. Evidently, however, the process of EU integration goes somewhat beyond the boundaries of Western civilization set by Huntington. The EU currently encompasses four predominantly Orthodox countries (Bulgaria, Cyprus, Greece and Romania), and it is in negotiations with other three predominantly Orthodox (Macedonia, Montenegro and Serbia) and two predominantly Muslim nations (Albania and Turkey). The analysis suggests that Western Europe, at least during the period analyzed here, might be pulling the cultures of other nations closer to the Western European average regardless of their cultural-historical background.

The major contribution of this paper is finding evidence for the importance of cultural diffusion as one of the most fundamental mechanisms of cultural change, in addition to the effect of socioeconomic development. The economic disparities between (north-)western Europe and the rest of the continent originated several centuries before the idea of a unified Europe was born (Welzel 2013) and can hardly be overcome by the much more recent and relatively short period of economic prosperity in other corners of the continent. Conversely, cultural diffusion appears to be highly effective in transforming national cultures and bringing them closer together even over a relatively short timeframe. This supports previous findings by Bonikowski (2010), who points to the political cooperation between nations as the mechanism that promotes value diffusion. This in turn leads to cultural convergence and occurs independently of changes in the countries' level of economic development.

With regard to the EU's democratic legitimation crisis due to the lack of a European demos (Weiler 1995) and the challenges entailed by cultural value differences in the course of integration (e.g., Gerhards 2007, Guiso et al. 2016, Hien 2017), this study provides an optimistic account of the recent cultural processes concerning EU integration. The European demos is not provided per se but is created as a result of the integrational efforts in other spheres and the intensified interactions between European public actors and common citizens. This evaluation aligns with another optimistic finding by Klingemann and Weldon (2013), who show that mutual trust between EU states has been rising since the very beginning of the project. This process has turned Germany and France, archenemies until 1945, into Europe's core allies. The authors point out that this was possible due to the institutional structure of the EU, which allows for increased levels of interaction and interconnectedness between member states. Such studies indicate that the EU has emerged as a powerful force that is transforming the continent slowly but profoundly.

Questions remain regarding how much value congruency is necessary, which particular values are essential and whether this has already been achieved. Recent political tensions in CEE indicate that the core democratic values, promoted by the EU, may not be sufficiently embedded in some former socialist societies that joined the EU in 2004. Another question that also deserves more consideration in future research is the relationship between cultural values and identities. This analysis demonstrates that Western European countries that meet the requirements but lack the support of their populations for membership diverge culturally from 
core EU members (albeit in a direction of much stronger democratic values). This finding can serve as a preliminary indication for the cultural development of the UK after its prospective withdrawal from the EU, which can be examined empirically when new waves of the WVS/EVS become available.

It should be acknowledged that the particular mechanisms leading to value convergence have not been the focus and cannot be determined based on this analysis. Intensified social interactions between member societies, intentional efforts made by EU actors to promote a certain value scheme or more likely all of these factors could be linked to value homogenization. The specific mechanisms that lead to convergence as well as divergence itself should be a topic for further research. Furthermore, the analysis depicts general macroscopic trends without focusing on particular cases. Another limitation of this analysis is its short time span. The analysis identified substantive cultural transformations, which indicates the plasticity of national cultures. However, it implies that changes in the reverse direction are also possible. The period after the collapse of communism created a vacuum in CEE when no viable alternatives to the Western path of development were present. Antiestablishment, eurosceptic right-wing parties were also less significant in Europe at the time, and the financial crisis had not yet tested the solidarity among members. Consequently, the period from 1992 to 2008 may have been especially favorable to such value transformations. Further analysis utilizing the upcoming waves of the WVS and EVS can shed more light on the long-term processes of European cultural integration.

Despite its motto "United in diversity," a more culturally homogenous European Union may be emerging. The analysis demonstrates that the EU may have remarkable potential to quickly integrate the values of the old, new and prospective member states. If it is not restricted by incompatible identities, this process may strengthen the legitimacy of the EU and provide momentum for further integration. 


\section{REFERENCES}

Akaliyski, P. (2017). Sources of Societal Value Similarities across Europe. Comparative Sociology 16(4): 447-470.

Aleman, J. \& Woods, D. (2016). Value Orientations From the World Values Survey: How Comparable Are They Cross-Nationally? Comparative Political Studies 49(8): 10391067.

Allison, P. D. (2009). Quantitative Applications in the Social Sciences: Fixed effects regression models. Thousand Oaks, CA: SAGE

Aronow, P. M., Samii, C. \& Assenova, V. A. (2015). Cluster-Robust Variance Estimation for Dyadic Data. Political Analysis 23(4): 564-577.

Atoyan, R. et al. (2016). Emigration and Its Economic Impact on Eastern Europe. Retrieved from https://www.imf.org/external/pubs/ft/sdn/2016/sdn1607.pdf

Belot, M. \& Ederveen, S. (2012). Cultural barriers in migration between OECD countries. Journal of Population Economics 25(3): 1077-1105.

Bonikowski, B. (2010). Cross-national interaction and cultural similarity: A relational analysis. International Journal of Comparative Sociology 51(5): 315-348.

Borzel, T. A. \& Risse, T. (2012). From Europeanisation to Diffusion: Introduction. West European Politics 35(1): 1-19.

Bove, V. \& Gokmen, G. (2016). Cultural Distance and Interstate Conflicts. British Journal of Political Science 1-11.

Cameron, A. C., Gelbach, J. B. \& Miller, D. L. (2011). Robust Inference with Multiway Clustering. Journal of Business \& Economic Statistics 29(2): 238-249.

Cappelen, A. et al. (2003). The impact of EU regional support on growth and convergence in the European Union. Journal of Common Market Studies 41(4):621-644.

Deutsch, F. \& Welzel, C. (2016). The Diffusion of Values among Democracies and Autocracies. Global Policy 7(4): 563-570.

Dietz, T. \& Kalof, L. (2009). Causation and Models of Causal Effects. In T. Dietz \& L. Kalof (Eds.), Introduction to Social Statistics: The Logic of Statistical Reasoning (pp. 183217): Wiley-Blackwell.

Dimaggio, P. J. \& Powell, W. W. (1983). The Iron Cage Revisited - Institutional Isomorphism And Collective Rationality In Organizational Fields. American Sociological Review 48(2): 147-160.

European Union ([1992] 2008). Consolidated version of the Treaty on European Union. Available online at: http://eurlex.europa.eu/LexUriServ/LexUriServ.do?uri=OJ:C:2008:115:0013:0045:en:PDF

Gerhards, J. (2007). Cultural overstretch? Differences between old and new member states of the EU and Turkey. London: Routledge.

Gerhards, J. (2008). Free to move? The acceptance of free movement of labour and non discrimination among citizens of Europe. European Societies 10(1): 121-140.

Gerhards, J. (2010). Non-Discrimination towards Homosexuality. The European Union's Policy and Citizens' Attitudes towards Homosexuality in 27 European Countries. International Sociology 25(1): 5-28.

Gerhards, J. \& Hoelscher, M. (2003). Cultural differences between present and future member countries of the European Union - The example of family and gender concepts. Zeitschrift Für Soziologie 32(3): 206-225. 
Gerhards, J. \& Lengfeld, H. (2006). The European Union's ecological script and its acceptance by the citizens of the EU member and candidate countries. Zeitschrift Für Soziologie 35(1): 24-40.

Gerhards, J., Schafer, M. S. \& Kampfer, S. (2009). Gender Equality in the European Union: The EU Script and its Support by European Citizens. Sociology-the Journal of the British Sociological Association 43(3): 515-534.

Goedeme, T. \& Collado, D. (2016). The EU Convergence Machine at Work. To the Benefit of the EU's Poorest Citizens? Journal of Common Market Studies 54(5): 1142-1158.

Guiso, L., Herrera, H. \& Morelli, M. (2016). Cultural Differences and Institutional Integration. Journal of International Economics 99: 97-113.

Guiso, L., Sapienza, P. \& Zingales, L. (2009). Cultural Biases in Economic Exchange? Quarterly Journal of Economics 124(3): 1095-1131.

Habermas, J. (2012). The Crisis of the European Union: A Response. Cambridge: Polity.

Headley, J. (2015). Challenging the EU's claim to moral authority: Russian talk of 'double standards'. Asia Europe Journal 13(3): 297-307.

Hien, J. (2017). The Religious Foundations of the European Crisis. Journal of Common Market Studies

Hofstede, G. (1991). Cultures and Organizations: Software of the Mind. McGraw-Hill International

Holton, R. (2000). Globalization's cultural consequences. Annals of the American Academy of Political and Social Science 570: 140-152.

Huntington, S. P. (1996). The clash of civilizations and the remaking of world order. New York: Simon \& Schuster.

Inglehart, R. \& Baker, W. E. (2000). Modernization, cultural change, and the persistence of traditional values. American Sociological Review 65(1): 19-51.

Inglehart, R. \& Welzel, C. (2005). Modernization, Cultural Change, and Democracy: The Human Development Sequence: Cambridge University Press.

Klingemann, H.-D. \& Weldon, S. (2013). A Crisis of Integration? The Development of Transnational Dyadic Trust in the European Union, 1954-2004. European Journal of Political Research 52(4):457-82.

Klingler-Vidra, R. \& Schleifer, P. (2014). Convergence More or Less: Why Do Practices Vary as They Diffuse? International Studies Review 16(2): 264-274.

Kraidy, M. M. (2002). Hybridity in cultural globalization. Communication Theory 12(3): 316339.

Lahdesmaki, T. (2016). Politics of tangibility, intangibility, and place in the making of a European cultural heritage in EU heritage policy. International Journal of Heritage Studies 22(10): 766-780.

Levitz, P. \& Pop-Eleches, G. (2010). Why No Backsliding? The European Union's Impact on Democracy and Governance Before and After Accession. Comparative Political Studies 43(4): 457-485.

Manners, I. (2002). Normative power Europe: A contradiction in terms? Journal of Common Market Studies 40(2): 235-258.

Meyer, J. W. et al. (1997). World society and the nation-state. American Journal of Sociology 103(1): 144-181.

Minkov, M. \& Hofstede, G. (2012). Is National Culture a Meaningful Concept? Cultural Values Delineate Homogeneous National Clusters of In-Country Regions. Cross-Cultural Research 46(2): 133-159. 
Minkov, M. \& Hofstede, G. (2014). Clustering of 316 European Regions on Measures of Values: Do Europe's Countries Have National Cultures? Cross-Cultural Research 48(2): 144-176.

Norris, P. \& Inglehart, R. (2002). Islamic culture and democracy: Testing the 'clash of civilizations' thesis. Comparative Sociology 1(3-4): 235-263.

Noutcheva, G. (2016). Societal Empowerment and Europeanization: Revisiting the EU's Impact on Democratization. Journal of Common Market Studies 54(3): 691-708.

"Official website of the European Union”. Retrieved January15, 2016 (http://europa.eu/abouteu/countries/index_en.htm)

Pieterse, J. N. (1994). Globalization as Hybridization. International Sociology, 9(2): 161-184.

Schwartz, S. (2006). A Theory of Cultural Value Orientations: Explication and Applications. Comparative Sociology 5(2-3).

Spaiser, V. et al. (2014). The Dynamics of Democracy, Development and Cultural Values. Plos One 9(6):11.

Tadesse, B. \& White, R. (2010). Does Cultural Distance Hinder Trade in Goods? A Comparative Study of Nine OECD Member Nations. Open Economies Review 21(2): 237-261.

Toggenburg, G. N. \& Grimheden, J. (2016). Upholding Shared Values in the EU: What Role for the EU Agency for Fundamental Rights? Journal of Common Market Studies 54(5): 1093-1104.

Vasilev, G. (2016). LGBT recognition in EU accession states: How identification with Europe enhances the transformative power of discourse. Review of International Studies, 42(4): 748-772.

Weiler, J. H. H. (1995). Does Europe Need a Constitution? Demos, Telos and the German Maastricht Decision. European Law Journal 1(3):219-58.

Welzel, C. (2013). Freedom Rising: Human Empowerment and the Quest for Emancipation: Cambridge University Press.

Welzel, C., Inglehart, R. \& Klingemann, H.-D. (2003). The theory of human development: A cross-cultural analysis. European Journal of Political Research 42: 341-379.

Welzel, C. \& Inglehart, R. F. (2016). Misconceptions of Measurement Equivalence. Comparative Political Studies, 49(8): 1068-1094.

Zapryanova, G. M. \& Surzhko-Harned, L. (2016). The effect of supranational identity on cultural values in Europe. European Political Science Review 8(4): 547-566.

"World Bank" World databank [Custom cross-tabulation of data]. Retrieved January 22, 2016 (http://databank.worldbank.org/data/reports.aspx?source=2\&series=NY.GDP.MKTP. CD\&country=)

World Values Survey 1981-2014 Longitudinal Aggregate v.20150418. World Values Survey Association (www.worldvaluessurvey.org). Aggregate File Producer: JDSystems, Madrid, Spain. 


\section{APPENDIX}

Table S2.A Dyadic distance in emancipative values regressed on EU membership and change from 1992 to 2008

\begin{tabular}{|c|c|c|c|c|c|c|}
\hline \multirow[b]{2}{*}{ Group of countries } & \multicolumn{2}{|c|}{$\begin{array}{c}\text { Average value distance } \\
\text { (estimated margins from OLS) }\end{array}$} & \multicolumn{2}{|c|}{$\begin{array}{l}\text { Change in average value distance } \\
\text { (unstandardized coeff. from FE) }\end{array}$} & \multirow{2}{*}{$\begin{array}{l}\text { Number of } \\
\text { dyads in } \\
\text { group }\end{array}$} & \multirow{2}{*}{$\begin{array}{c}\text { Number of } \\
\text { countries in } \\
\text { group }\end{array}$} \\
\hline & $\begin{array}{c}\text { Model I } \\
1992\end{array}$ & $\begin{array}{c}\text { Model II } \\
1992\end{array}$ & $\begin{array}{c}\text { Model III } \\
1992-2008\end{array}$ & $\begin{array}{l}\text { Model IV } \\
1992-2008\end{array}$ & & \\
\hline $\begin{array}{l}\text { Among EU founders (ref. for } \\
\text { Models I and II) }\end{array}$ & $\begin{array}{l}.066 \\
(.014)\end{array}$ & $\begin{array}{l}.047 \\
(.029)\end{array}$ & $\begin{array}{l}-.008 \\
(.014)\end{array}$ & $\begin{array}{l}-.002 \\
(.014)\end{array}$ & 10 & 5 \\
\hline Founders and old members & $\begin{array}{l}.081 \\
(.008)\end{array}$ & $\begin{array}{l}.069 \\
(.017)\end{array}$ & $\begin{array}{l}-.011 \\
(.006)\end{array}$ & $\begin{array}{l}-.013+ \\
(.006)\end{array}$ & 45 & 14 \\
\hline Founders and new members & $\begin{array}{l}.091 \\
(.011)\end{array}$ & $\begin{array}{l}.104 \\
(.023)\end{array}$ & $\begin{array}{c}-.027 * * \\
(.006)\end{array}$ & $\begin{array}{l}-.042 * * \\
(.010)\end{array}$ & 50 & 15 \\
\hline Founders and Schengen area & $\begin{array}{l}.094 \\
(.018)\end{array}$ & $\begin{array}{l}.080 \\
(.026)\end{array}$ & $\begin{array}{l}. \mathbf{0 4 4} * * \\
(.014)\end{array}$ & $\begin{array}{l}.056 * * \\
(.015)\end{array}$ & 10 & 7 \\
\hline Founders and nonmembers & $\begin{array}{l}.093 \\
(.015)\end{array}$ & $\begin{array}{l}.108 \\
(.025)\end{array}$ & $\begin{array}{l}.057 * * \\
(.011)\end{array}$ & $\begin{array}{l}. \mathbf{0 5 0} * * \\
(.012)\end{array}$ & 15 & 8 \\
\hline Among nonmembers & $\begin{array}{l}.035+ \\
(.008)\end{array}$ & $\begin{array}{c}.027 \\
(.018)\end{array}$ & $\begin{array}{c}.043 \\
(.026)\end{array}$ & $\begin{array}{l}.042 \\
(.026)\end{array}$ & 3 & 3 \\
\hline $\begin{array}{l}\text { Control for GDP/capita } \\
\mathrm{R}^{2} \\
\mathrm{R}^{2} \text { (within) }\end{array}$ & $\begin{array}{l}\text { No } \\
.03\end{array}$ & $\begin{array}{l}\text { Yes } \\
.05\end{array}$ & No & $\begin{array}{l}\text { Yes } \\
.32\end{array}$ & Total: 133 & Total: 29 \\
\hline
\end{tabular}

Notes: Two-way cluster-robust standard errors in parentheses. ${ }^{* *} \mathrm{p}<0.01,{ }^{*} \mathrm{p}<0.05+\mathrm{p}<0.1$. Significance tests in model I and II refers to the difference compared to the reference category. In model III and IV, it shows whether the change over time within this group of countries is statistically significant. OLS - ordinary least-squared regression. FE - fixed-effects regression. The groups of countries include only dyads where one country belongs to the first groups and the other to the second group. E.g., "Founders and old members" includes pairs of one founder and one old member but not two founders or two old members.

Notes on EU membership for the data sample: EU members are as of 2016. Non-EU members exclude non-EU Schengen area nations. EU Founders: Belgium, France, Germany, Italy and Netherlands. Old Members: Austria, Denmark, Finland, Ireland, Portugal, Spain, Sweden and Great Britain. Schengen area (nonEU): Iceland and Norway. New members: Bulgaria, Czechia, Estonia, Hungary, Latvia, Malta, Poland, Romania, Slovakia and Slovenia. Nonmembers (and non-EU Schengen area): Belarus, Russia and Turkey. 
Table S2.B Dyadic distance in secular values regressed on EU membership and change from 1992 to 2008

\begin{tabular}{|c|c|c|c|c|c|c|}
\hline \multirow[b]{2}{*}{ Group of countries } & \multicolumn{2}{|c|}{$\begin{array}{c}\text { Average value distance } \\
\text { (estimated margins from OLS) }\end{array}$} & \multicolumn{2}{|c|}{$\begin{array}{l}\text { Change in average value distance } \\
\text { (unstandardized coeff. from FE) }\end{array}$} & \multirow{2}{*}{$\begin{array}{c}\text { Number of } \\
\text { dyads in } \\
\text { group }\end{array}$} & \multirow{2}{*}{$\begin{array}{c}\text { Number of } \\
\text { countries in } \\
\text { group }\end{array}$} \\
\hline & $\begin{array}{c}\text { Model I } \\
1992\end{array}$ & $\begin{array}{c}\text { Model II } \\
1992\end{array}$ & $\begin{array}{c}\text { Model III } \\
1992-2008\end{array}$ & $\begin{array}{l}\text { Model IV } \\
1992-2008\end{array}$ & & \\
\hline $\begin{array}{l}\text { Among EU founders (ref. for } \\
\text { Models I and II) }\end{array}$ & $\begin{array}{l}.045 \\
(.012)\end{array}$ & $\begin{array}{l}.012 \\
(.022)\end{array}$ & $\begin{array}{l}.014 \\
(.011)\end{array}$ & $\begin{array}{l}.017 \\
(.011)\end{array}$ & 10 & 5 \\
\hline Founders and old members & $\begin{array}{l}.072+ \\
(.006)\end{array}$ & $\begin{array}{l}.052 * \\
(.013)\end{array}$ & $\begin{array}{l}-.011 * \\
(.005)\end{array}$ & $\begin{array}{l}-.012 * \\
(.005)\end{array}$ & 45 & 14 \\
\hline Founders and new members & $\begin{array}{l}.073+ \\
(.008)\end{array}$ & $\begin{array}{l}.096 * \\
(.016)\end{array}$ & $\begin{array}{l}-.005 \\
(.005)\end{array}$ & $\begin{array}{l}-.010 \\
(.008)\end{array}$ & 50 & 15 \\
\hline Founders and Schengen area & $\begin{array}{c}.059 \\
(.007)\end{array}$ & $\begin{array}{c}.035 \\
(.015)\end{array}$ & $\begin{array}{l}-.003 \\
(.011)\end{array}$ & $\begin{array}{l}.000 \\
(.012)\end{array}$ & 10 & 7 \\
\hline Founders and nonmembers & $\begin{array}{l}.086+ \\
(.022)\end{array}$ & $\begin{array}{l}. \mathbf{1 1 3} * \\
(.026)\end{array}$ & $\begin{array}{l}.017+ \\
(.009)\end{array}$ & $\begin{array}{l}.014 \\
(.009)\end{array}$ & 15 & 8 \\
\hline Among nonmembers & $\begin{array}{l}.155 \\
(.062)\end{array}$ & $\begin{array}{l}.142 * \\
(.060)\end{array}$ & $\begin{array}{l}.029 \\
(.021)\end{array}$ & $\begin{array}{l}.029 \\
(.021)\end{array}$ & 3 & 3 \\
\hline $\begin{array}{l}\text { Control for GDP/capita } \\
\mathrm{R}^{2}\end{array}$ & $\begin{array}{l}\text { No } \\
.07\end{array}$ & $\begin{array}{c}\text { Yes } \\
.09\end{array}$ & No & Yes & Total: 133 & Total: 29 \\
\hline $\mathrm{R}^{2}$ (within) & & & .09 & .10 & & \\
\hline
\end{tabular}

Notes: Two-way cluster-robust standard errors in parentheses. ${ }^{* *} \mathrm{p}<0.01,{ }^{*} \mathrm{p}<0.05+\mathrm{p}<0.1$. Significance tests in model I and II refers to the difference compared to the reference category. In model III and IV, it shows whether the change over time within this group of countries is statistically significant. OLS - ordinary least-squared regression. FE - fixed-effects regression. The groups of countries include only dyads where one country belongs to the first groups and the other to the second group. E.g., "Founders and old members" includes pairs of one founder and one old member but not two founders or two old members.

Notes on EU membership for the data sample: EU members are as of 2016. Non-EU members exclude non-EU Schengen area nations. EU Founders: Belgium, France, Germany, Italy and Netherlands. Old Members: Austria, Denmark, Finland, Ireland, Portugal, Spain, Sweden and Great Britain. Schengen area (nonEU): Iceland and Norway. New members: Bulgaria, Czechia, Estonia, Hungary, Latvia, Malta, Poland, Romania, Slovakia and Slovenia. Nonmembers (and non-EU Schengen area): Belarus, Russia and Turkey. 
Table S3.A Dyadic distance in emancipative values regressed on EU membership and change from 2001 to 2008

\begin{tabular}{|c|c|c|c|c|c|c|}
\hline \multirow[b]{2}{*}{ Group of countries } & \multicolumn{2}{|c|}{$\begin{array}{c}\text { Average value distance } \\
\text { (estimated margins from OLS) }\end{array}$} & \multicolumn{2}{|c|}{$\begin{array}{l}\text { Change in average value distance } \\
\text { (unstandardized coeff. from FE) }\end{array}$} & \multirow{2}{*}{$\begin{array}{l}\text { Number of } \\
\text { dyads in } \\
\text { group }\end{array}$} & \multirow{2}{*}{$\begin{array}{c}\text { Number of } \\
\text { countries in } \\
\text { group }\end{array}$} \\
\hline & $\begin{array}{c}\text { Model I } \\
2001\end{array}$ & $\begin{array}{c}\text { Model II } \\
2001\end{array}$ & $\begin{array}{l}\text { Model III } \\
2001-2008\end{array}$ & $\begin{array}{l}\text { Model IV } \\
\text { 2001-2008 }\end{array}$ & & \\
\hline $\begin{array}{l}\text { Among Old EU members (ref. for } \\
\text { Models I and II) }\end{array}$ & $\begin{array}{c}.069 \\
(.005)\end{array}$ & $\begin{array}{c}.079 \\
(.009)\end{array}$ & $\begin{array}{c}.004 \\
(.003)\end{array}$ & $\begin{array}{c}.004 \\
(.003)\end{array}$ & 119 & 16 \\
\hline Old EU members and new members & $\begin{array}{l}. \mathbf{0 9 9} * * \\
(.005)\end{array}$ & $\begin{array}{c}.098 \\
(.005)\end{array}$ & $\begin{array}{c}-.023 * * \\
(.002)\end{array}$ & $\begin{array}{c}\mathbf{- . 0 3 2} * * \\
(.003)\end{array}$ & 176 & 27 \\
\hline Old EU members and candidates & $\begin{array}{l}. \mathbf{1 7 8}^{* *} \\
(.009)\end{array}$ & $\begin{array}{l}. \mathbf{. 1 7 3}^{* *} \\
(.010)\end{array}$ & $\begin{array}{c}-.037 * * \\
(.004)\end{array}$ & $\begin{array}{c}-\mathbf{. 0 4 2} * * \\
(.004)\end{array}$ & 64 & 20 \\
\hline Old EU members and noncandidates & $\begin{array}{l}. \mathbf{1 6 9} \text { ** } \\
(.006)\end{array}$ & $\begin{array}{l}. \mathbf{1 6 3}^{* * *} \\
(.008)\end{array}$ & $\begin{array}{l}. \mathbf{0 0 9} * * \\
(.003)\end{array}$ & $\begin{array}{c}.004 \\
(.003)\end{array}$ & 128 & 25 \\
\hline Among non-members (noncandidates) & $\begin{array}{c}.058 \\
(.006)\end{array}$ & $\begin{array}{c}.065 \\
(.008) \\
\end{array}$ & $\begin{array}{l}-.001 \\
(.007)\end{array}$ & $\begin{array}{c}.000 \\
(.007)\end{array}$ & 28 & 8 \\
\hline Control for GDP/capita & No & Yes & No & Yes & Total: 515 & Total: 39 \\
\hline $\mathrm{R}^{2}$ & .28 & .29 & & & & \\
\hline $\mathrm{R}^{2}$ (within) & & & .22 & .24 & & \\
\hline
\end{tabular}

Notes: Two-way cluster-robust standard errors in parentheses. ${ }^{* *} \mathrm{p}<0.01,{ }^{*} \mathrm{p}<0.05+\mathrm{p}<0.1$. Significance tests in model I and II refers to the difference compared to the reference category. In model III and IV it shows whether the change over time within this group of countries is statistically significant. OLS - ordinary least-squared regression. FE - fixed-effects regression. The groups of countries include only dyads where one country belongs to the first groups and the other to the second group. E.g., "Founders and old members" includes pairs of one founder and one old member but not two founders or two old members.

Old EU members: Austria, Belgium, Denmark, Finland, France, Germany, Greece, Ireland, Italy, Luxembourg, Netherlands, Spain and Sweden. New members: Bulgaria, Croatia, Czechia, Estonia, Hungary, Latvia, Lithuania, Malta, Poland, Romania, Slovakia and Slovenia. Candidates: Albania, Montenegro, Serbia and Turkey. Noncandidates: Azerbaijan, Armenia, Bosnia and Herzegovina, Belarus, Georgia, Moldova, Russia and Ukraine. 
Table S3.B Dyadic distance in secular values regressed on EU membership and change from 2001 to 2008

\begin{tabular}{|c|c|c|c|c|c|c|}
\hline \multirow[b]{2}{*}{ Group of countries } & \multicolumn{2}{|c|}{$\begin{array}{c}\text { Average value distance } \\
\text { (estimated margins from OLS) }\end{array}$} & \multicolumn{2}{|c|}{$\begin{array}{l}\text { Change in average value distance } \\
\text { (unstandardized coeff. from FE) }\end{array}$} & \multirow{2}{*}{$\begin{array}{l}\text { Number } \\
\text { of dyads } \\
\text { in group }\end{array}$} & \multirow{2}{*}{$\begin{array}{c}\text { Number of } \\
\text { countries in } \\
\text { group }\end{array}$} \\
\hline & $\begin{array}{c}\text { Model I } \\
2001\end{array}$ & $\begin{array}{l}\text { Model II } \\
2001\end{array}$ & $\begin{array}{l}\text { Model III } \\
\text { 2001-2008 }\end{array}$ & $\begin{array}{l}\text { Model IV } \\
\text { 2001-2008 }\end{array}$ & & \\
\hline $\begin{array}{l}\text { Among Old EU members (ref. for } \\
\text { Models I and II) }\end{array}$ & $\begin{array}{l}.057 \\
(.003)\end{array}$ & $\begin{array}{l}.036 \\
(.006)\end{array}$ & $\begin{array}{l}-.002 \\
(.003)\end{array}$ & $\begin{array}{l}-.002 \\
(.003)\end{array}$ & 119 & 16 \\
\hline Old EU members and new members & $\begin{array}{l}\mathbf{0 7 5} * * \\
(.004)\end{array}$ & $\begin{array}{l}.078 * * \\
(.004)\end{array}$ & $\begin{array}{l}-.007 * \\
(.003)\end{array}$ & $\begin{array}{l}-.009 * \\
(.004)\end{array}$ & 176 & 27 \\
\hline Old EU members and candidates & $\begin{array}{l}.078 * \\
(.008)\end{array}$ & $\begin{array}{l}. \mathbf{0 8 8} * * \\
(.008)\end{array}$ & $\begin{array}{l}-.001 \\
(.005)\end{array}$ & $\begin{array}{l}-.002 \\
(.005)\end{array}$ & 64 & 20 \\
\hline Old EU members and noncandidates & $\begin{array}{l}.068 * \\
(.004)\end{array}$ & $\begin{array}{l}.081 * * \\
(.005)\end{array}$ & $\begin{array}{l}-.004 \\
(.003)\end{array}$ & $\begin{array}{l}-.006 \\
(.003)\end{array}$ & 128 & 25 \\
\hline Among non-members (noncandidates) & $\begin{array}{l}. \mathbf{0 8 5}^{*} \\
(.010)\end{array}$ & $\begin{array}{l}.071 * * \\
(.010)\end{array}$ & $\begin{array}{l}-.005 \\
(.007)\end{array}$ & $\begin{array}{l}-.004 \\
(.007)\end{array}$ & 28 & 8 \\
\hline $\begin{array}{l}\text { Control for GDP/capita } \\
\mathrm{R}^{2}\end{array}$ & $\begin{array}{l}\text { No } \\
.03\end{array}$ & $\begin{array}{l}\text { Yes } \\
.05\end{array}$ & No & Yes & Total: 515 & Total: 39 \\
\hline $\mathrm{R}^{2}$ (within) & & & .02 & .02 & & \\
\hline
\end{tabular}

Notes: Two-way cluster-robust standard errors in parentheses. ${ }^{*} \mathrm{p}<0.01,{ }^{*} \mathrm{p}<0.05+\mathrm{p}<0.1$. Significance tests in model I and II refers to the difference compared to the reference category. In model III and IV it shows whether the change over time within this group of countries is statistically significant. OLS - ordinary least-squared regression. FE - fixed-effects regression. The groups of countries include only dyads where one country belongs to the first groups and the other to the second group. E.g., "Founders and old members" includes pairs of one founder and one old member but not two founders or two old members.

Old EU members: Austria, Belgium, Denmark, Finland, France, Germany, Greece, Ireland, Italy, Luxembourg, Netherlands, Spain and Sweden. New members: Bulgaria, Croatia, Czechia, Estonia, Hungary, Latvia, Lithuania, Malta, Poland, Romania, Slovakia and Slovenia. Candidates: Albania, Montenegro, Serbia and Turkey. Noncandidates: Azerbaijan, Armenia, Bosnia and Herzegovina, Belarus, Georgia, Moldova, Russia and Ukraine. 
Figure S1 Availability and interpolation of data from WVS and EVS. Blue (1) - real survey data; green (0) - interpolated data.

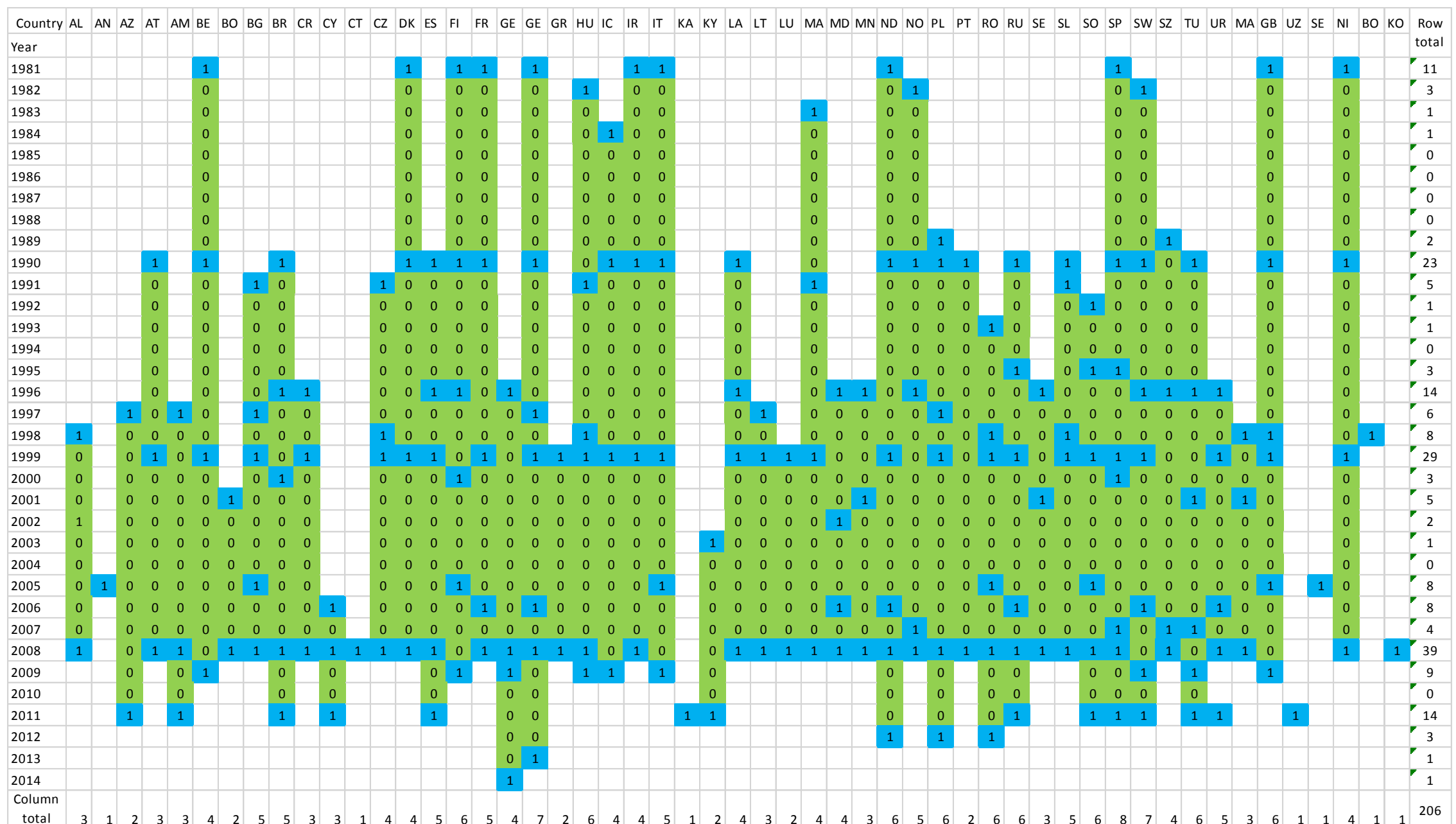

Note: this figure shows which year each country has been surveyed but not if full data on relevant variables are actually available. 